\title{
Analysis and comparison of the sporting regulations of Capoeira (1973 and 2012): What about the fight?
}

Ana Rosa JAQUEIRA*, \& Paulo Coêlho ARAÚJO

Faculty of Sport Sciences and Physical Education. University of Coimbra / LUDUS: Games Lab, Recreation, Traditional Fights and Capoeira

\section{Introduction}

39 years have passed between the preparation of the 1973 Capoeira Technical Regulation (RTC) and the 2012 National Sports Regulation for Competitions Amateur, Adapted, School and High Performance (RNSCAASHP), by the National Authority for Administration and Sports Representation, the Brazilian Capoeira Confederation (CBC). Our aim is to interpret and compare these regulatory documents and understand the organizational maturity of this modality as an element of sports competition, and the quality (type) of competitions it covers. It should be noted that the 1973 Regulation is the first sports regulation of Capoeira known in its history, and the 2012 document is the latest to which we had access, via on-line availability.

\section{Justification}

Despite the 1973 RTC regulation and the diverse studies produced about the Brazilian fighting since then, only Jaqueira (2010) focused on the analysis of its transition to sports and regulation (Jaqueira \& Araújo, 2013a), as well as the ancient characteristics of Capoeira (Jaqueira \& Araújo, 2013b), and on historical considerations on the regulatory process at that time (Jaqueira \& Araújo, 2013c). Given the need for sports organization felt by the capoeiristas, as well as the globalization of Capoeira, currently administered and represented by the International Federation of Capoeira, which keeps organic links with the $\mathrm{CBC}$, it is extremely necessary to know the documents that rule the competitions in this Brazilian fight, in order to fit it with criterion, objective, and viable in the competitive context.

\section{Methodology}

To interpret and compare the 1973 and 2012 regulations, we applied a multi-method process, using ethnographic (Baztan, 1995) and historical (Lalande, 2012) methods, content (Bardin, 1995), and praxiological (Lagardera \& Lavega, 2003) analysis, essential for the processing and interpretation of data.

\section{Analysis and discussion of results}

The Motor Praxiology or Science of Motor Action allowed us to classify, categorize and compare elements of the 1973 and 2012 regulations, to identify, through the analysis of its Internal Logic (IL) that these documents reflect the sports modality according to how capoeiristas interpret and express Capoeira: a game, a stylized group expression, a gymnic expression or the expression of fight. The contextual aspects such as historical, cultural, gender, age, organizational protocols, arbitration, clothing, musical instruments, the ritualistic features, among others, not directly linked to motor action itself, are considered elements of the External Logic (EL) of a motor expression. In 
other words, the IL combines content that define the modality, which are fundamental to its achievement, elementary aspects in the pact design between the protagonists of the action. Without these aspects the expression cannot be effective, whereas in the absence of EL elements definition, the expression can be realized.

Through the praxiological analysis of the regulations in question, we understood what was the expressiveness of Capoeira that the mentors of these documents where referring to and what was the idea of Capoeira they wanted to reveal. While the Regulation (1973) had thirty-two chapters belonging to the EL of Capoeira, ten of them to IL, the 2012 Regulation has eleven parts and seventy-eight articles, with only three parts dedicated to sports competition itself, and among them, only nineteen articles refer to the LI of Capoeira. From the three parts that aim to regulate the sports competition of Capoeira, none of them is dedicated to the expression Capoeira fight. Even the "individual" combats, this is to say, a one-to-one confront, are attack and defense simulations, not being allowed the effectiveness of blows, but simulation of movements.

\section{Conclusions}

The LE prevalence over LI highlighted in 1973 and the strong emphasis marginal factors to fight competition has become an unavoidable fact in the 2012 document. The RNSCAASHP in general, seeks to define spaces other than the sports competition of Capoeira, starting also for the scopes of competitions compositions of theoretical and musical works on the subject, and the formation of arbitrators, sometimes known as jurors. Nevertheless, without highlighting regulatory combat aspects (on-to-one) in particular. It's been observed that the 2012 document, in particular, partly reflects the Capoeira scenario as a multifaceted contemporary expression, but that inevitably excludes from its historical dynamics its original fighting aspect, through a pseudo speech of pacification of its agonistic spirit or of civilizational aspect, introducing sports terms like fair-play, and the substitution of the word blow by the word movement, which mean very different motor actions. The observed need of controlling the inadequate and pervert conducts (Lavega, 2015) of its practitioners who act and those who do not act in a competitive context, is also demonstrative of the organizational immaturity from those who play capoeira, and reveals how they act in a competition scenario.

We conclude that over all these years, the regulatory official entity promoted Capoeira eliminating its original characteristic of fight. What prevailed is a weak sports regulation of the game, the artistic and gymnic group expression, which prevents the effective and controlled combat of its techniques, as can be seen in other forms of fighting.

\section{References}

Bardin, L. (1995). Análise de conteúdo. Lisboa: Edições 70.

Baztán, A. A. (1995). Etnografia. Barcelona: Editorial BoixareuUniversitaria/Marcombo.

Confederação Brasileira de Capoeira (2012). Regulamento Desportivo Nacional para Competições Amadoras, Adaptadas, Escolares e de Alto Rendimento. Retrieved from http://www.ondeachocapoeira.com.

Jaqueira, A. R. (2010). Fundamentos histórico-sociais do processo de desportivização e de regulamentação desportiva da Capoeira. Tese de Doutoramento FCDEFUC. Coimbra.

Jaqueira, A. R., \& Araújo, P. C. (2013a). Análise praxiológica do primeiro regulamento desportivo da capoeira. Revista Movimento, 19(2), 31-53.

Jaqueira, A. R. , \& Araújo, P. C. (2013b). Análise comparativa das propostas cariocas e baiana para a regulamentação desportiva da capoeira (1968). Revista de Artes Marciales Asiáticas, 7(2), 12-26.

Jaqueira, A. R., \& Araújo, P. C. (2013c). Considerações histórico-sociais sobre as primeiras propostas de regulamentação desportiva da Capoeira. Recorde: Revista de História do Esporte, 6(1) 1-40.

Lagardera, F., \& Lavega, P. (2003). Introducción a la Praxiología Motriz. Barcelona: Paidotribo.

Lalande, A. (1926/1993). Letures sur la Philosophie des Sciences. Retrieved from http://www.filoinfo.bem-vindo.net/node/557

Key words: Capoeira; combat sports; fight; regulations. 